University of Nebraska - Lincoln

DigitalCommons@University of Nebraska - Lincoln

Agronomy \& Horticulture -- Faculty Publications

Agronomy and Horticulture Department

2016

\title{
Corn Response to Nitrogen Management under Fully-Irrigated vs. Water-Stressed Conditions
}

\author{
Bijesh Maharjan \\ University of Nebraska-Lincoln, bmaharjan@unl.edu \\ Carl J. Rosen \\ University of Minnesota, St.Paul, crosen@umn.edu \\ John A. Lamb \\ University of Minnesota, St. Paul \\ Rodney T. Venterea \\ University of Minnesota, St. Paul
}

Follow this and additional works at: https://digitalcommons.unl.edu/agronomyfacpub

Part of the Agricultural Science Commons, Agriculture Commons, Agronomy and Crop Sciences Commons, Botany Commons, Horticulture Commons, Other Plant Sciences Commons, and the Plant Biology Commons

Maharjan, Bijesh; Rosen, Carl J.; Lamb, John A.; and Venterea, Rodney T., "Corn Response to Nitrogen Management under Fully-Irrigated vs. Water-Stressed Conditions" (2016). Agronomy \& Horticulture -Faculty Publications. 1174.

https://digitalcommons.unl.edu/agronomyfacpub/1174

This Article is brought to you for free and open access by the Agronomy and Horticulture Department at DigitalCommons@University of Nebraska - Lincoln. It has been accepted for inclusion in Agronomy \& Horticulture -Faculty Publications by an authorized administrator of DigitalCommons@University of Nebraska - Lincoln. 


\title{
Corn Response to Nitrogen Management under Fully-Irrigated vs. Water-Stressed Conditions
}

\author{
Bijesh Maharjan, Carl J. Rosen,* John A. Lamb, and Rodney T. Venterea
}

\begin{abstract}
Characterizing corn (Zea mays L.) grain yield (GY) response to $\mathrm{N}$ is critical for maximizing profits, increasing $\mathrm{N}$ use efficiency and minimizing environmental impacts. Although a large database of GY response to N exists for highly productive soils, few data exist for less productive soils. While changes in precipitation are expected in the future, few studies have compared GY response to varying $\mathrm{N}$ management practices under conditions of varying water availability. We measured GY and basal stalk nitrate nitrogen (BSN) at harvest using split-applied urea at eight $\mathrm{N}$ rates under fully-irrigated (FI) and water-stressed (WS) conditions in a loamy sand over 2 yr (2009 and 2010). We also measured GY and BSN using single, pre-plant applications of urea, polymer-coated urea (PCU) and urea amended with urease and nitrification inhibitors (IU) at one or two $\mathrm{N}$ rates. The results showed that economic optimum nitrogen rate (EONR) and agronomic optimum nitrogen rate (AONR) did not vary by water management, in spite of significant increases in GY (up to $48 \%$ ) under FI compared to WS. Modification of N fertilizer timing or N source was effective for increasing GY (by 18-41\%) with FI, but did not affect GY under WS conditions. Averaged across years, $\mathrm{BSN}$ was greater with WS compared to $\mathrm{FI}$ at most $\mathrm{N}$ rates; however, $\mathrm{BSN}$ corresponding to AONR was within the optimal range for both water regimes. These findings may have important implications in areas where changes in irrigation practices or water availability are expected under future climate conditions.
\end{abstract}

\section{Core Ideas}

- Better understanding of water stress effects on corn response to $\mathrm{N}$ is needed.

- We measured yield response to $\mathrm{N}$ management with full irrigation and under water-stress.

- Optimum $\mathrm{N}$ rate did not vary by water management despite significant yield differences.

- Optimizing fertilizer timing or source increased yield but only with full irrigation.

- Basal stalk nitrate was higher with water-stress than with full irrigation.

Published in Agron. J. 108:2089-2098 (2016)

doi:10.2134/agronj2016.01.0006

Received 4 Jan. 2016

Accepted 13 May 2016

Available freely online through the author-supported open access option

Copyright $\odot 2016$ American Society of Agronomy

5585 Guilford Road, Madison, WI 53711 USA

This is an open access article distributed under the CC BY-NC-ND

license (http://creativecommons.org/licenses/by-nc-nd/4.0/)

\section{Raditional approaches to $\mathrm{N}$ rate recommenda- tions have been based primarily on GY goal (Stanford, 1973), soil organic matter content (Mulvaney et al.,} 2001) and, in some cases, previous crop and residual soil nitrate $\left(\mathrm{NO}_{3}{ }^{-}\right)$(Zebarth et al., 2001; Blackmer et al., 1997). While these approaches may make intuitive sense, a compilation of field experiments with corn showed a weak relationship between EONR and maximum GY (Sawyer et al., 2006). A different approach for $\mathrm{N}$ fertilizer rate recommendations in the upper Midwest was developed based on more than 600 field corn trials in several states (Sawyer et al., 2006). However, a potential constraint of current guidelines is that they are based on response curves in highly productive soils and limited data are available for coarse-textured soils.

It is well known that corn is highly sensitive to water stress (El-Hendawy and Schmidhalter, 2010; NeSmith and Ritchie, 1992), and timely irrigation increases yield (Stone et al., 2010) especially on sandy soils (Maharjan et al., 2014). However, irrigation, coupled with unpredictable rainfall, can increase risk of $\mathrm{N}$ loss through leaching, especially if $\mathrm{N}$ is applied at rates greater than the optimum required for corn production (Ludwick et al., 1976; Al-Kaisi and Yin, 2003). Thus, it is not clear if EONR-based $\mathrm{N}$ rate recommendations based on more productive, irrigated soils will also apply to non- or minimallyirrigated systems. While numerous studies have been conducted to determine $\mathrm{N}$ response under irrigated conditions (Endelman et al., 1974; Gehl et al., 2005; Ludwick et al., 1976; Stone et al., 2010) few have compared N response with true replication under similar soil and climatic conditions when water availability changes. Adjusting water availability with

B. Maharjan, Dep. Soil, Water, and Climate University of Minnesota, St. Paul, MN 55108; current address Dep. Agronomy and Horticulture, University of Nebraska, Lincoln, NE 68583; C.J. Rosen and J.A. Lamb, Dep. Soil, Water, and Climate University of Minnesota, St. Paul, MN 55108; R.T. Venterea, Dep. Soil, Water, and Climate University of Minnesota, St. Paul, MN 55108 and USDA-ARS, Soil and Water Management Unit, 1991 Upper Buford Circle, St. Paul, MN 55108. Mention of trade names or commercial products in this publication is solely for the purpose of providing specific information and does not imply recommendation or endorsement by the USDA, University of Minnesota, or University of Nebraska-Lincoln. The USDA is an equal opportunity provider and employer. ${ }^{*}$ Corresponding author (crosen@umn.edu).

Abbreviations: ANU, aboveground nitrogen uptake; AONR, agronomic optimum nitrogen rate; BSN, basal stalk nitrate nitrogen; EONR, economic optimum nitrogen rate; FI, fully irrigated; GY, grain yield; IU, urea with urease and nitrification inhibitors; NFRE, nitrogen fertilizer recovery efficiency; PCU, polymer-coated urea; pre-U, pre-plant application of urea; split-U, split application of urea; WS, water-stressed. 
irrigation on coarse-textured soils provides an opportunity to evaluate $\mathrm{N}$ response under contrasting yield potentials.

The use of specialized "controlled-release" $\mathrm{N}$ fertilizer sources, including PCU and urea amended with IU, has the potential to minimize $\mathrm{NO}_{3}{ }^{-}$leaching (Wilson et al., 2010; Zvomuya et al., 2003) and nitrous oxide emissions (Halvorson et al., 2010; Hyatt et al., 2010). There is some concern, however, about the effectiveness of PCU and IU under dryland conditions because of erratic release rates with fluctuating soil moisture (Fujinuma et al., 2009) and studies showing limited or no effectiveness (Sistani et al., 2011; Venterea et al., 2011). It is not well understood how the agronomic effectiveness of controlled-release $\mathrm{N}$ sources may be affected by variation in water availability or management. Furthermore, changes in water availability to support irrigation, as well as changes in demand for irrigation sources, are predicted for many regions across the United States and the world, caused by projected changes in precipitation and temperature (Liu et al., 2013; McDonald and Girvetz, 2013; Yoshikawa et al., 2014). Thus, better understanding of how water stress affects corn response to $\mathrm{N}$ rate and other $\mathrm{N}$ management practices is needed to adapt management to changing climate.

Basal stalk $\mathrm{NO}_{3}{ }^{-}-\mathrm{N}$ has been widely used as a diagnostic tool to determine $\mathrm{N}$ status of corn (Binford et al., 1990). The basis for this test is that $\mathrm{NO}_{3}{ }^{-}$tends to accumulate in the lower portion of corn stalks under stress conditions including drought, as well as following over-application of $\mathrm{N}$ fertilizers and manure (Hanway and Englehorn, 1958). Post-harvest BSN measurements can potentially be useful in guiding $\mathrm{N}$ management in subsequent growing seasons. However, the reliability of BSN under varying water and $\mathrm{N}$ management is not known.

The objectives of this study were to quantify (i) corn GY, aboveground nitrogen uptake (ANU), nitrogen fertilizer recovery efficiency (NFRE), and BSN responses to $\mathrm{N}$ fertilizer rate in a coarse-textured soil under fully-irrigated (FI) and waterstressed (WS) conditions; (ii) EONR and AONR under FI and WS regimes; and (iii) the agronomic response to different $\mathrm{N}$ management systems comprised of varying combinations of $\mathrm{N}$ source, rate, and timing under FI and WS regimes.

\section{MATERIALS AND METHODS}

\section{Site Description and Experimental Design}

The study was conducted at the University of Minnesota's Sand Plain Research Farm in Becker, $\mathrm{MN}\left(45^{\circ} 23^{\prime} \mathrm{N}\right.$,

$93^{\circ} 53^{\prime} \mathrm{W}$ ), over the course of two consecutive growing seasons (2009 and 2010) using adjacent sections of the farm each year. The soil is a Hubbard loamy sand (sandy, mixed, frigid Entic Hapludoll) containing 820,100 , and $80 \mathrm{~g} \mathrm{~kg}^{-1}$ of sand, silt, and clay, respectively, in the upper $0.15 \mathrm{~m}$. Soil organic matter by loss on ignition (Combs and Nathan, 1998) was $23 \mathrm{~g} \mathrm{~kg}^{-1}$, pH (1:1 soil/water) (Peters et al., 2012) was 5.7, Bray-1 P (Frank et al., 1998) was $24 \mathrm{~g} \mathrm{~kg}^{-1}$ and ammonium acetate extractable K (Warncke and Brown, 1998) was $79 \mathrm{~g} \mathrm{~kg}^{-1}$ in samples from the 0 - to $0.15-\mathrm{m}$ depth. Pre-season total inorganic $\mathrm{N}$ $\left(\mathrm{NO}_{3}{ }^{-}+\mathrm{NH}_{4}{ }^{+}\right)($Gelderman and Beegle, 1998) in the upper $0.6 \mathrm{~m}$ was 20 and $19 \mathrm{~kg} \mathrm{~N} \mathrm{ha}^{-1}$ in 2009 and 2010, respectively. The 30-yr average precipitation and daily temperature during the growing season (1 April through 31 October) are $531 \mathrm{~mm}$ and $16.0^{\circ} \mathrm{C}$, respectively (MCWG, 2013). An onsite weather station (WatchDog Model 2800 Spectrum Technologies Inc, Plainfield, IL) was used to measure air temperature and precipitation at 10 -min intervals.

For 3 yr prior to the experiment, the fields were planted to non-irrigated winter rye (Secale cereal L.) fertilized with $35 \mathrm{~kg} \mathrm{~N} \mathrm{ha}^{-1} \mathrm{yr}^{-1}$. During each of these years, rye grain was harvested in summer followed by a rye winter cover crop that was incorporated by chisel and disking each spring together with potassium chloride and potassium-magnesium sulfate fertilizers each broadcast applied at the rate of $224 \mathrm{~kg} \mathrm{ha}^{-1}$. The current experiments were then established using a randomized complete block split-plot design with four blocks, where irrigation was the main plot factor and $\mathrm{N}$ fertilizer management was the subplot factor. In this region of the state and on this soil type, corn is grown under both irrigated and rain-fed conditions. However, a preliminary experiment conducted at the site in 2008 found that completely non-irrigated corn had almost a complete loss of GY ( $<15 \%$ of irrigated corn yield, unpublished data, 2008). Therefore, experiments in two subsequent years compared standard irrigation to minimal irrigation applied only to prevent extreme water stress during pollination. Irrigation treatments were designated as (i) fully-irrigated (FI), where main plots were irrigated based on the checkbook method for determining frequency and amount of water inputs as described in Wright (2002), and (ii) water-stressed (WS), where main plots were not irrigated except in mid-season (July and early August) when soil matric potential at 0.3-m depth was $\leq-50 \mathrm{KPa}$ for two to four consecutive days and coincided with matric potential $\leq-100 \mathrm{KPa}$ at $1.2-\mathrm{m}$ depth. Irrigation in all cases was applied using an aluminum solid-set overhead sprinkler system.

Each of the main FI and WS plots was subdivided into 12,6 by $10.7 \mathrm{~m}$ subplots, which were assigned randomly to different $\mathrm{N}$ management treatments (Table 1) consisting of: (i1) an unfertilized control, (2-8) split application of urea (46-0-0) (split-U) at rates of 45, 90, 135, 180, 225, 270, and $315 \mathrm{~kg} \mathrm{~N} \mathrm{ha}^{-1}$, respectively, (9) pre-plant application of urea (pre-U) at $180 \mathrm{~kg} \mathrm{~N} \mathrm{ha}^{-1}$, (10-11) pre-plant application of PCU (44-0-0) (ESN; Agrium Advanced Technologies, Loveland, CO) at 180 and $225 \mathrm{~kg} \mathrm{~N} \mathrm{ha}^{-1}$, respectively, and (12) one pre-plant application of IU (46-0-0) (Super U; Agrotain International, St. Louis, MO) at $180 \mathrm{~kg} \mathrm{~N} \mathrm{ha}^{-1}$. The IU treatment had urease inhibitor $\mathrm{N}$-(n-Butyl)-thiophosphoric triamide and nitrification inhibitor dicyandiamide. All treatments including the control received $5.6 \mathrm{~kg} \mathrm{~N}^{-1}$ of liquid fertilizer placed with the seed at planting as 10-34-0. Except for the pre-plant $\mathrm{N}$ treatments, $\mathrm{N}$ was applied in two split applications for the WS treatments and in three split applications for the FI treatments. The first urea application was applied $2 \mathrm{wk}$ after emergence and the second was applied at the V6-V8 stage; both were surface-applied manually within $20 \mathrm{~cm}$ of the rows and incorporated with mechanical cultivation to a depth of $8 \mathrm{~cm}$. The third urea application in the FI treatments was applied at initial tasseling using ureaammonium nitrate followed by irrigation to simulate fertigation, which is a recommended practice with full irrigation but not advisable under dryland production (Rehm et al., 2008). Pre-plant treatments were applied as a broadcast application and then incorporated by disking. Table 1 provides additional 


\begin{tabular}{|c|c|c|c|c|c|}
\hline N Treatment & Pre-plant $\dagger$ & $\begin{array}{c}2 \text { wk after emergence } \\
\text { (as urea) }\end{array}$ & $\begin{array}{c}\text { 3-4 wk after emergence } \\
\text { (as urea) }\end{array}$ & $\begin{array}{c}\text { 6-7 wk after emergence } \\
\text { (as 28\% UAN) }\end{array}$ & Total $\mathrm{N} \ddagger$ \\
\hline & & & $\mathrm{kg} \mathrm{N} \mathrm{ha}{ }^{-1}$ & 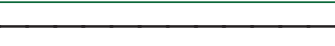 & 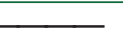 \\
\hline \multicolumn{6}{|c|}{ a. Fully-irrigated } \\
\hline I & 0 & 0 & 0 & 0 & 0 \\
\hline 2 & 0 & 22.5 & 22.5 & 0 & 45 \\
\hline 3 & 0 & 45 & 22.5 & 22.5 & 90 \\
\hline 4 & 0 & 67 & 34 & 34 & 135 \\
\hline 5 & 0 & 90 & 56 & 34 & 180 \\
\hline 6 & 0 & 112 & 79 & 34 & 225 \\
\hline 7 & 0 & 135 & 101 & 34 & 270 \\
\hline 8 & 0 & 157 & 124 & 34 & 315 \\
\hline 9 & $180 \mathrm{~N}$ as urea & 0 & 0 & 0 & 180 \\
\hline 10 & $180 \mathrm{~N}$ as $\mathrm{PCU}$ & 0 & 0 & 0 & 180 \\
\hline II & $225 \mathrm{~N}$ as $\mathrm{PCU}$ & 0 & 0 & 0 & 225 \\
\hline 12 & $180 \mathrm{~N}$ as IU & 0 & 0 & 0 & 180 \\
\hline \multicolumn{6}{|c|}{ b.Water-stressed } \\
\hline I & 0 & 0 & 0 & 0 & 0 \\
\hline 2 & 0 & 22.5 & 22.5 & 0 & 45 \\
\hline 3 & 0 & 45 & 45 & 0 & 90 \\
\hline 4 & 0 & 67.5 & 67.5 & 0 & 135 \\
\hline 5 & 0 & 90 & 90 & 0 & 180 \\
\hline 6 & 0 & 113 & 112 & 0 & 225 \\
\hline 7 & 0 & 135 & 135 & 0 & 270 \\
\hline 8 & 0 & 158 & 157 & 0 & 315 \\
\hline
\end{tabular}

† Applied 7 and $3 \mathrm{~d}$ before planting in 2009 and 2010, respectively.

$\ddagger$ Does not include liquid popup $\mathrm{N}$ fertilizer applied at planting at the rate of $5.6 \mathrm{~kg} \mathrm{~N} \mathrm{ha}^{-1}$ as $10-34-0$.

details regarding source, rate, and timing of $\mathrm{N}$ fertilizer treatments. Corn (Syngenta N40T Series 99) was planted at a rate of 79,000 seeds ha- $\mathrm{ha}^{-1}$ for FI and 68,000 seed ha ${ }^{-1}$ for WS on 8 May 2009 and 26 Apr. 2010. Use of reduced seeding rates for WS is a standard grower practice in the area, which reduces competition for water and the possibility of water stress in dry years (Barr et al., 2013). Irrigation water had nitrate- $N$ concentrations of 9 to $11 \mathrm{mg} \mathrm{L}^{-1}$ and provided additional $\mathrm{N}$ inputs of 35 and $3 \mathrm{~kg} \mathrm{~N} \mathrm{ha}^{-1}$, respectively, in the FI and WS treatments in 2009, and 28 and $2 \mathrm{~kg} \mathrm{~N} \mathrm{ha}^{-1}$, respectively, in 2010. Irrigation inputs of $\mathrm{N}$ were not considered in the current data analysis because farmers typically do not consider irrigation water in their $\mathrm{N}$ management plans when nitrate- $\mathrm{N}$ concentrations are $<10 \mathrm{mg} \mathrm{L}^{-1}$ (Lamb et al., 2015), and because irrigation can increase leaching losses of $\mathrm{N}$ (Maharjan et al., 2014), thus negating the increased $\mathrm{N}$ input.

\section{Crop Measurements}

After physiological maturity, corn ears were harvested by hand from $6.1 \mathrm{~m}$ of row from each of the middle two rows of each subplot. Ears were dried, shelled, and further dried for $3 \mathrm{~d}$ at $65^{\circ} \mathrm{C}$ and weighed to obtain dry grain and cob yield. Stover yield was estimated by measuring the weight of eight random stalks per plot from the middle two rows where corn ears were harvested. Subsamples of grain, cob, and stover tissue were collected to determine moisture content at harvest and then ground to determine $\mathrm{N}$ concentrations in each plant component (i.e., grain, cob, and stover) using an elemental $\mathrm{N}$ combustion analyzer (VarioEL; Elementar, Hanau, Germany).
Aboveground nitrogen uptake (ANU) was calculated from the sum of $\mathrm{N}$ harvested in grain, cob, and stoverexpressed on a dry mass basis. For BSN, 0.20-m stalk sample segments were collected $0.15 \mathrm{~m}$ above the ground from 12 plants in each plot. Samples were dried to constant weight at $65^{\circ} \mathrm{C}$, ground using a Wiley mill and then extracted with water for subsequent BSN determination (Carlson et al., 1990). The BSN results were categorized into excessive, optimal, marginal, and low ranges as defined by Blackmer and Mallarino (1996). Relative $\mathrm{N}$ use efficiency was expressed as $\mathrm{N}$ fertilizer recovery efficiency (NFRE, \%), calculated using $\left(B_{\mathrm{f}} B_{0}\right) / F \times 100$, where $B$ is ANU $\left(\mathrm{kg} \mathrm{N} \mathrm{ha}^{-1}\right), F$ is fertilizer $\mathrm{N}$ applied $\left(\mathrm{kg} \mathrm{N} \mathrm{ha}^{-1}\right)$ and the subscripts $f$ and 0 refer to values for a given treatment and the zero$\mathrm{N}$ control treatment, respectively, within the same block.

\section{Data Analysis}

Treatments 1 to 8 (Table 1 ) all received conventional urea at varying $\mathrm{N}$ rates and are therefore referred to as comprising the "Urea $\mathrm{N}$ rate" study. Data from these treatments were analyzed separately to evaluate effects of year, irrigation, and $\mathrm{N}$ rate on crop response variables. Treatments 5 to 6 and 9 to 12 received varying $\mathrm{N}$ sources (urea, PCU, or IU) with either pre-plant or post-plant split application timing, with an $\mathrm{N}$ rate of either 180 or $225 \mathrm{~kg} \mathrm{~N} \mathrm{ha}^{-1}$. Therefore, data from these treatments are referred to as comprising the "Source/timing/rate" study and were analyzed separately to evaluate effects of year, irrigation, and $\mathrm{N}$ management "system", where each system consisted of a combination of source, timing, and rate. Treatment effects on crop response variables were evaluated using Proc Mixed in 
SAS with year, irrigation, and $\mathrm{N}$ rate (in the urea $\mathrm{N}$ rate study) or $\mathrm{N}$ management system (in the source/timing/rate study) treated as fixed effects, and with block, and all interactions of block with other terms, treated as random effects (Littell et al., 2006; SAS, 2003). Year was treated as a fixed effect to evaluate effects of differences in weather between growing seasons. Data from Treatments 1 to 8 were also used to calculate AONR and EONR (Cerrato and Blackmer, 1990). The AONR was determined for each block using a quadratic plateau model in SAS (SAS, 2003). The EONR was determined for each block using the same statistical model obtained for the AONR and by assuming a ratio of 5.6 between the cost of a kilogram of $\mathrm{N}$ and price of a kilogram of corn (this is equivalent to a ratio of 0.1 for the cost in U.S. dollars of a pound of $\mathrm{N}$ and price of a bushel of corn). Treatment effects on AONR and ENOR were evaluated using Proc Mixed in SAS with year and irrigation treated as fixed effects and with block, and all interactions of block with other terms, treated as random effects (Littell et al., 2006; SAS Institute, 2003). Additional pairwise comparisons were conducted in the source/timing/rate study to compare $\mathrm{N}$ sources applied at the same rate using contrasts in SAS with significance criteria of $P<0.05$. Results from second-order polynomial regression to determine relationship between $\mathrm{N}$ rate and several of the dependent variables were expressed as the square of the coefficients of correlation $\left(R^{2}\right)$.

\section{RESULTS}

\section{Climate and Irrigation}

Total growing season (1April through 31 October) precipitation was 532 and $732 \mathrm{~mm}$, respectively in 2009 and 2010 compared to the $30-\mathrm{yr}$ average $(531 \mathrm{~mm})$ (Fig. 1). As a result of greater rainfall in 2010, the amount and frequency of irrigation in 2010 was reduced compared to 2009. In 2010, there were 12 rainfall events $>20 \mathrm{~mm} \mathrm{~d}^{-1}$ compared to six such events in 2009. The average daily mean temperature in 2010 was $17.4^{\circ} \mathrm{C}$, compared with $15.8^{\circ} \mathrm{C}$ in 2009 . By month, average daily mean temperature was greater in 2010 than in 2009 by $0.6^{\circ} \mathrm{C}$ in May, $1.0^{\circ} \mathrm{C}$ in June, $3.3^{\circ} \mathrm{C}$ in July and August, and $5.2^{\circ} \mathrm{C}$ in October, while September in 2010 was cooler by $3.6^{\circ} \mathrm{C}$ compared with 2009 .

\section{Urea Nitrogen Rate Study}

There was a significant irrigation $\times \mathrm{N}$ rate interaction effect on GY and BSN (Table 2). While GY was always significantly greater in FI compared to WS, the magnitude of differences varied by $\mathrm{N}$ rate (Fig. 2). In both years, $\mathrm{BSN}$ tended to be greater in WS compared to FI, but was significantly greater only at specific $\mathrm{N}$ rates (Fig. 3). Significant year $\times N$ rate interaction effects were observed for GY, ANU, and NFRE

(Fig. 4) as well as BSN (Fig. 5). Grain yield and ANU tended to be greater in 2009 than 2010, but the differences were significant only at specific $\mathrm{N}$ rates (Fig. $4 \mathrm{a}, 4 \mathrm{~b}$ ). The NFRE was significantly greater in 2010 than 2009 at $90 \mathrm{~kg} \mathrm{~N} \mathrm{ha}^{-1}$, but in contrast NFRE was significantly greater in 2009 than 2010 at $270 \mathrm{~kg} \mathrm{~N} \mathrm{ha}^{-1}$ and did not differ by year at other $\mathrm{N}$ rates (Fig. 4c). Averaged across years (Fig. 2) and across irrigation regimes (Fig. 4a), GY was well-described by quadratic plateau models. Averaged across water management treatments, ANU was well described by a second-order polynomial model $\left(R^{2}=0.98\right)$ and increased in response to increasing $\mathrm{N}$ rate (Fig. $4 \mathrm{~b}$ ). In 2010, NFRE was well described by a decreasing second-order polynomial model $\left(R^{2}=0.92\right)$. However, in 2009 NFRE was less well described by a polynomial model $\left(R^{2}=0.60\right)$ and exhibited apparent maximum values at intermediate $\mathrm{N}$ rates (Fig. 4c). Averaged over irrigation treatments, BSN increased with increasing $\mathrm{N}$ rate both years but tended to be greater in 2010 than 2009 at all rates except the $90 \mathrm{~kg} \mathrm{ha}^{-1}$ rate (Fig. 5)

Although EONR and AONR were numerically greater in the FI treatment compared to WS averaged across years (Fig. $2)$, irrigation management did not significantly affect EONR $(P=0.55)$ or AONR $(P=0.71)$ (Table 2$)$. Similarly, while there was an apparent trend for greater $\operatorname{EONR}(P=0.10)$ and $\operatorname{AONR}(P=0.12)$ in 2009 compared to 2010 averaged across irrigation regimes, year did not significantly affect EONR or AONR (Table 2, Fig. 3a). When averaged across years,

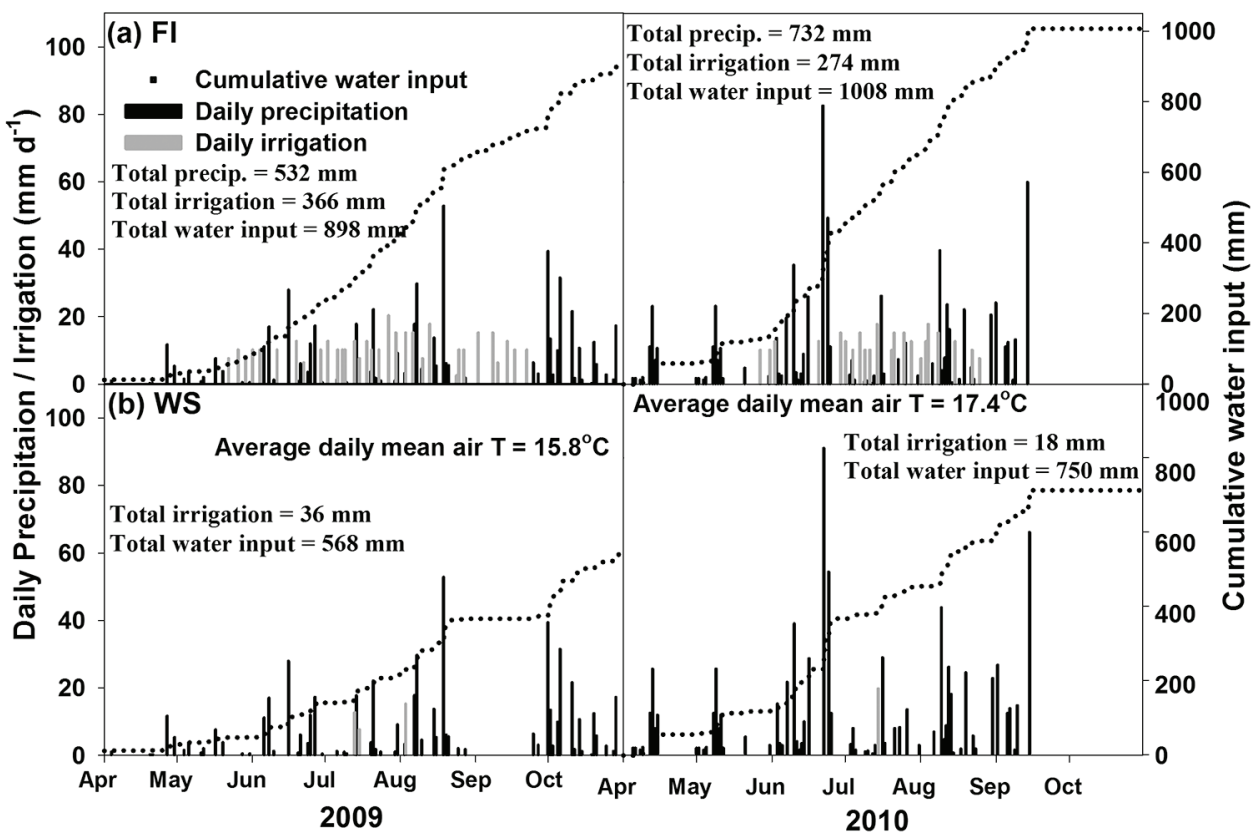

Fig. I. Weather and irrigation information during the 2009 and 2010 growing seasons for (a) fully irrigated and (b) water-stressed treatments. 
Table 2. Results ( $P$ values) of statistical analysis of crop response to year, irrigation, and $\mathrm{N}$ rate in the urea- $\mathrm{N}$ rate study.

\begin{tabular}{|c|c|c|c|c|c|c|}
\hline Source of variation & GYt & ANU & BSN & NFRE & EONR & AONR \\
\hline Year $(Y) \ddagger$ & 0.0227 & 0.0178 & 0.0016 & 0.4019 & 0.0991 & 0.1196 \\
\hline Irrigation (I)§ & $<0.0001$ & 0.0003 & 0.0007 & 0.1933 & 0.5548 & 0.7144 \\
\hline N Rate $(\mathrm{N}) \mathrm{T}$ & $<0.0001$ & $<0.0001$ & $<0.0001$ & $<0.0001$ & na\# & na \\
\hline \multicolumn{7}{|l|}{ Interactions } \\
\hline$Y^{\prime} \mid$ & 0.1360 & 0.7117 & 0.6615 & 0.3694 & 0.6563 & 0.7389 \\
\hline $\mathrm{Y} \times \mathrm{N}$ & 0.0366 & $<0.0001$ & $<0.0001$ & 0.0048 & na & na \\
\hline $\mathrm{I} \times \mathrm{N}$ & 0.0125 & 0.389 & 0.0122 & 0.5798 & na & na \\
\hline$Y^{\prime} \mid \times N$ & $0.4|4|$ & $0.727 \mid$ & 0.2273 & 0.9844 & na & na \\
\hline
\end{tabular}

† GY is grain yield, ANU is aboveground nitrogen uptake, BSN is basal stalk nitrate nitrogen, NFRE is nitrogen fertilizer recovery efficiency, EONR is economic optimum nitrogen rate, AONR is agronomic optimum nitrogen rate.

$\ddagger$ Year includes 2009 and 2010 .

§Irrigation treatments include fully-irrigated (FI) and water-stressed (WS).

Tा Nitrogen rate includes in-season applied urea at rates of $0,45,90,135,180,225,270$, and $315 \mathrm{~kg} \mathrm{~N} \mathrm{ha}{ }^{-1}$

\# na is not applicable.

BSN values corresponding to AONR fell within the optimal (700-2000 $\mathrm{mg} \mathrm{NO}_{3}{ }^{-}-\mathrm{N} \mathrm{kg}^{-1}$ ) range for both $\mathrm{FI}$ and WS treatments (Fig. 3b). Similarly, when averaged over irrigation management, BSN levels corresponding to AONR were within the optimum range in both years (Fig. $5 b$ ).

\section{Source/Timing/Rate Study}

There were significant irrigation $\times \mathrm{N}$ management system and year $\times$ irrigation interaction effects on GY (Table 3). Averaged across years, GY was consistently greater in FI than WS for all N management systems (Fig. 6a). Within the WS irrigation regime, $\mathrm{N}$ management system did not significantly affect GY. In contrast, within the FI irrigation regime, GY was significantly greater with split-applied urea (180 and $\left.225 \mathrm{~kg} \mathrm{~N} \mathrm{ha}^{-1}\right)$ and pre-plant-applied PCU $\left(225 \mathrm{~kg} \mathrm{~N} \mathrm{ha}^{-1}\right)$ compared to pre-plant applied PCU $\left(180 \mathrm{~kg} \mathrm{~N} \mathrm{ha}^{-1}\right)$, preplant applied IU $\left(180 \mathrm{~kg} \mathrm{~N} \mathrm{ha}^{-1}\right)$ and pre-plant applied urea $\left(180 \mathrm{~kg} \mathrm{~N} \mathrm{ha}^{-1}\right)$, which had lower GY than all other treatments (Fig. 6a). Averaged across $\mathrm{N}$ management systems, GY was greater in 2009 than 2010 for both the FI and WS treatments (Fig. 6b).

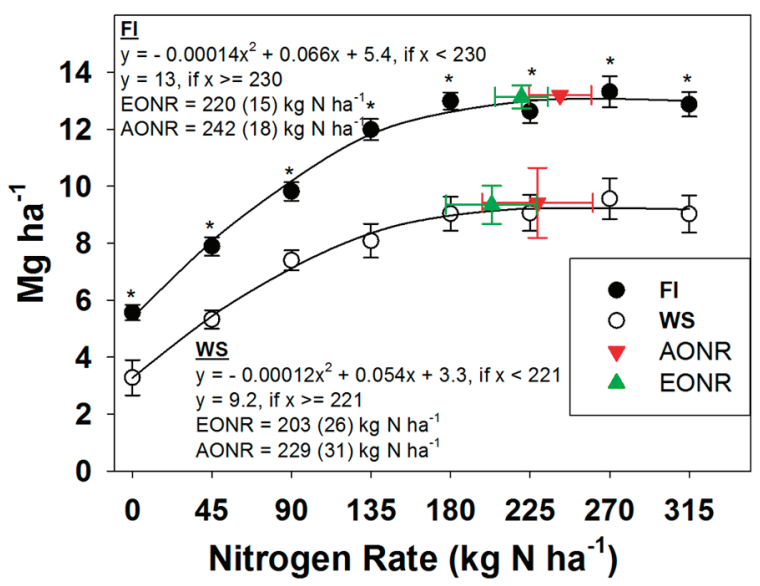

Fig. 2. Means (standard error) of grain yield in the urea $\mathrm{N}$ rate study under fully-irrigated (FI) (closed circles) and water-stressed (WS) (open circles) conditions where the irrigation $\times \mathrm{N}$ rate interaction effect was significant. Quadratic-plateau models are fitted for both FI and WS treatments. Mean (standard error) values of agronomic and economic optimum $\mathrm{N}$ rates (AONR and EONR) are represented by red (red inverted triangle) and green (green triangle) symbols, respectively.
Significant year $\times$ irrigation $\times N$ management effects were observed for ANU, BSN, and NFRE (Tables 3 and 4). In 2010, ANU was significantly greater in FI than WS for all N management systems. In 2009, ANU was greater in FI than WS with Split-U (180 and $\left.225 \mathrm{~kg} \mathrm{~N} \mathrm{ha}^{-1}\right)$, but ANU was greater in WS than FI with Pre-U $\left(180 \mathrm{~kg} \mathrm{~N} \mathrm{ha}^{-1}\right)$ and PCU $\left(180 \mathrm{~kg} \mathrm{~N} \mathrm{ha}^{-1}\right)$. The BSN was greater in WS than FI for all systems except split-U at 180 and $225 \mathrm{~kg} \mathrm{~N} \mathrm{ha}^{-1}$ in 2009 . In 2010, BSN was greater in WS than FI for two systems (split-U at $180 \mathrm{~kg} \mathrm{~N} \mathrm{ha}^{-1}$ and IU at $180 \mathrm{~kg} \mathrm{~N} \mathrm{ha}^{-1}$ ) but did not differ

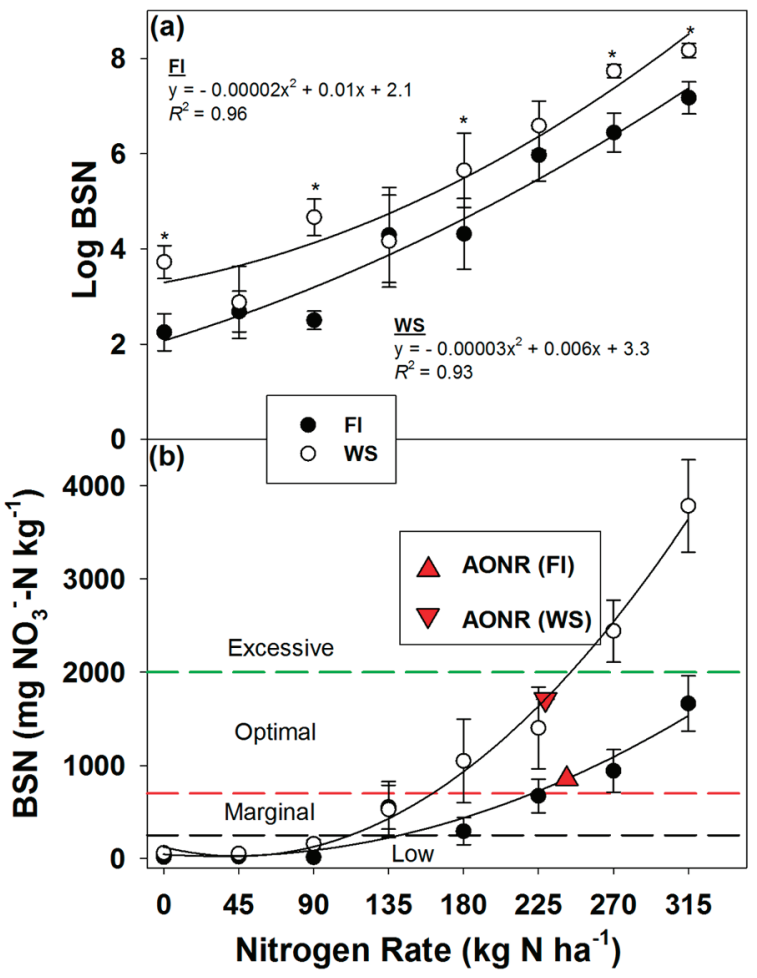

Fig. 3. Means (standard error) of basal stalk nitrate nitrogen (BSN) for fully-irrigated (FI) treatments (closed circles) and water-stressed (WS) treatments (open circles) in the urea $N$ rate study where the irrigation $\times \mathrm{N}$ rate interaction effect was significant. Original analyses were conducted on the log of BSN data shown in (a). Lines represent fitted polynomial models. Asterisks $(*)$ indicate significant differences between $\mathrm{FI}$ and WS at $P c<c 0.05$ for a given $\mathrm{N}$ rate. In (b), colored horizontal lines represent boundaries between excessive, optimal, marginal, and low BSN categories (Blackmer and Mallarino, 1996). 
by water management in the other systems. In 2009, NFRE was greater in FI than WS with Split-U $\left(180 \mathrm{~kg} \mathrm{~N} \mathrm{ha}^{-1}\right)$, but greater in WS than FI for Pre-U, PCU, and IU all applied at $180 \mathrm{~kg} \mathrm{~N} \mathrm{ha}^{-1}$. Irrigation did not significantly affect NFRE in 2010.

Averaged across irrigation treatments, based on pair-wise comparisons among the four $\mathrm{N}$ management systems where $180 \mathrm{~kg} \mathrm{~N} \mathrm{ha}^{-1}$ was applied, Split-U had greater GY, ANU, and NFRE than Pre-U, PCU, and IU, while all crop response variables were significantly greater in PCU and IU compared to Pre-U (data not shown). Split-U (180 $\left.\mathrm{kg} \mathrm{N} \mathrm{ha}^{-1}\right)$ also had greater BSN than PCU $\left(180 \mathrm{~kg} \mathrm{~N} \mathrm{ha}^{-1}\right)$. In pair-wise comparisons of Split-U and PCU, both applied at $225 \mathrm{~kg} \mathrm{~N} \mathrm{ha}^{-1}$, no significant differences were observed for any response variables (data not shown).

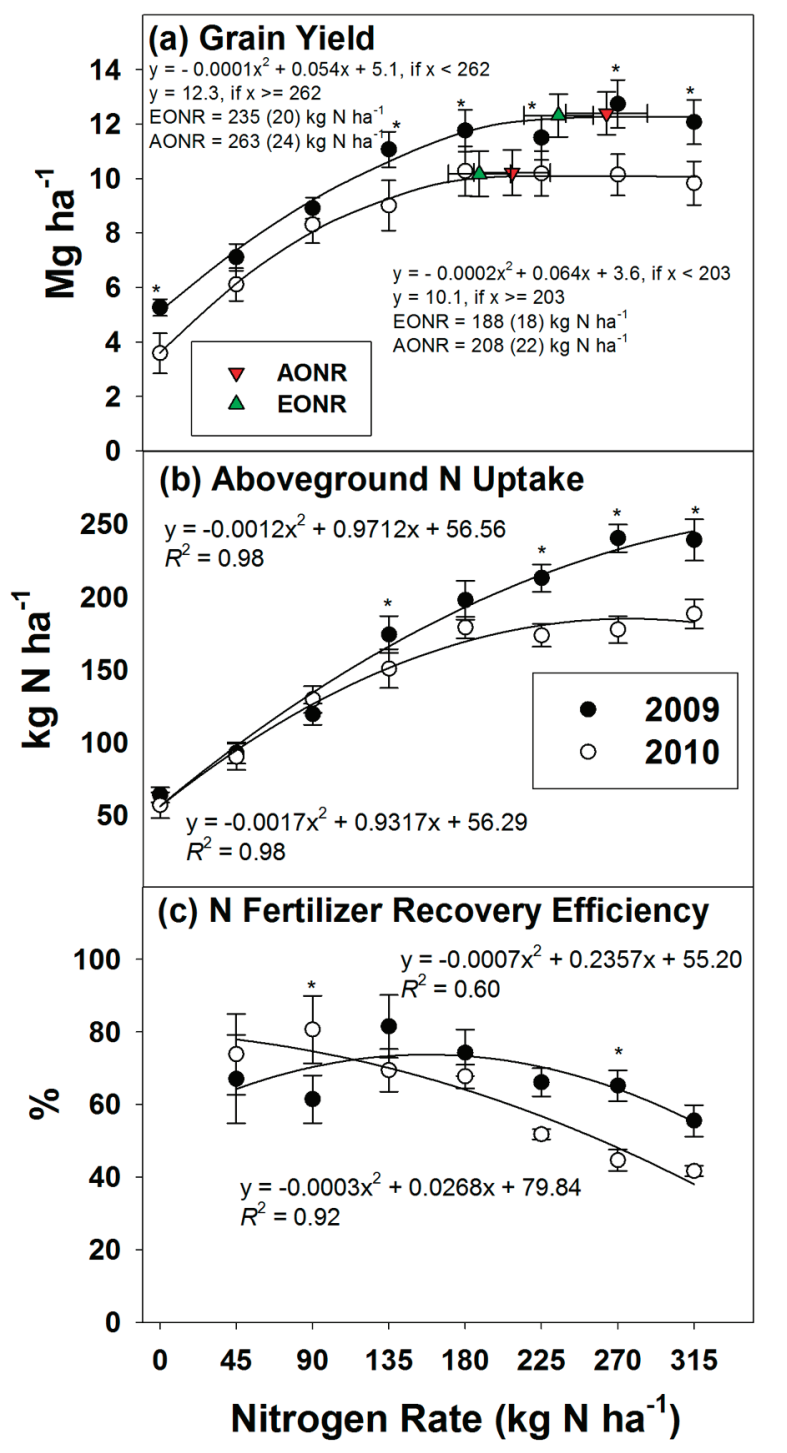

Fig. 4. Means (standard error) of (a) grain yield, (b) aboveground $\mathrm{N}$ uptake, and (c) $\mathrm{N}$ fertilizer recovery in the urea $\mathrm{N}$ rate study averaged across irrigation treatments for 2009 (closed circles) and 2010 (open circle). Asterisks (*) indicate significant differences between years at $P<0.05$ for a given $\mathrm{N}$ rate. Lines represent fitted quadratic-plateau (a) or polynomial (b and c) models. Mean (standard error) values of agronomic and economic optimum $\mathrm{N}$ rates (AONR and EONR) are represented by red (red inverted triangle) and green ( green triangle) symbols, respectively, with corresponding yields predicted by the models. In (b) and (c), lines represent fitted polynomial models.

\section{DISCUSSION}

\section{Urea Nitrogen Rate Study}

Numerous studies have reported reduction in corn GY as a result of water stress on canopy development (Oktem, 2008; Stone et al., 2001) and kernel number and weight (Karam et al., 2003; Pandey et al., 2000). In the current study, GY significantly increased with irrigation as reported in other studies (Simsek et al., 2011; Yi et al., 2011; NeSmith and Ritchie, 1992) at all $\mathrm{N}$ rates in both years. As expected, irrigation scheduled according to the checkbook method was more effective than the reduced irrigation treatment of this study.

In 2010, precipitation events were more frequent, more intense, and greater in total amount than in 2009. Significantly greater $\mathrm{NO}_{3}{ }^{-}$leaching was reported in 2010 compared to 2009 in the $180 \mathrm{~kg} \mathrm{~N} \mathrm{ha}^{-1}$ treatments in the same research plots (Maharjan et al., 2014). This possibly explains lower GY and ANU in 2010 compared to 2009 at some $\mathrm{N}$ rates in the current study. It is well known that precipitation occurring in larger events can cause significant $\mathrm{N}$ loss, thus affecting yield. For example, $25.4 \mathrm{~mm}$ (1 inch) of irrigation or rainfall has been shown to result in the transport of soil $\mathrm{NO}_{3}{ }^{-}$a distance of 150 to $200 \mathrm{~mm}$ in a loamy sand (Endelman et al., 1974). These results therefore suggest that even when using split $\mathrm{N}$ application, which is generally recommended as a best management practice to reduce $\mathrm{N}$ loss, large rainfall events can result in substantial loss of yield.

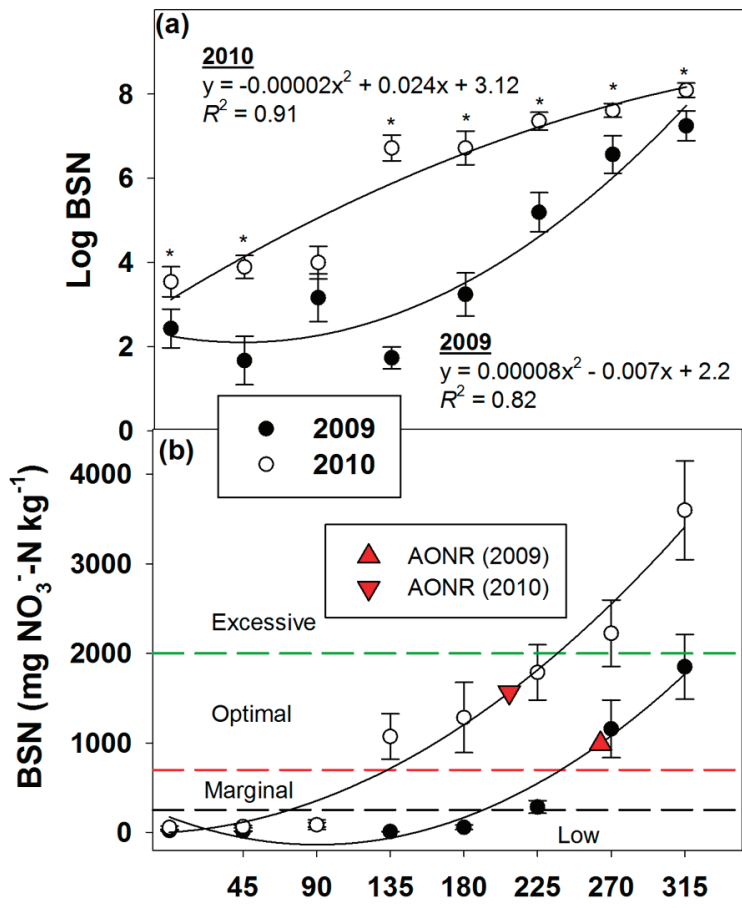

Nitrogen Rate ( $\mathrm{kg} \mathrm{N} \mathrm{ha}^{-1}$ )

Fig. 5. Means (standard error) of basal stalk nitrate nitrogen (BSN) in the urea $\mathrm{N}$ rate study averaged across irrigation treatments for 2009 (closed circle) and 2010 (open circle). Original analyses were conducted on the log of BSN data shown in (a). Lines represent fitted polynomial models. Asterisks (*) indicate significant differences between 2009 and 2010 at $P<0.05$ for a given $\mathrm{N}$ rate. In plate (b), colored horizontal lines represent boundaries between excessive, optimal, marginal, and low BSN categories (Blackmer and Mallarino, 1996). 
Table 3. Results (P values) of statistical analysis of crop response to year, irrigation and $\mathrm{N}$ management system in the source/timing/rate/study.

\begin{tabular}{|c|c|c|c|c|}
\hline Source of variation & GY† & ANU & BSN & NFRE \\
\hline Year $(Y) \ddagger$ & 0.0042 & 0.0017 & 0.0080 & 0.0057 \\
\hline Irrigation $(\mathrm{I}) \S$ & $<0.0001$ & 0.0069 & $<0.0001$ & 0.0236 \\
\hline $\mathrm{N}$ management system $(\mathrm{N}) \mathrm{T}$ & $<0.0001$ & $<0.0001$ & $<0.0001$ & $<0.0001$ \\
\hline \multicolumn{5}{|l|}{ Interactions } \\
\hline$Y \times 1$ & 0.0062 & 0.0017 & 0.0011 & 0.0221 \\
\hline $\mathrm{Y} \times \mathrm{N}$ & 0.1229 & 0.0584 & $<0.0001$ & 0.0173 \\
\hline $\mathrm{I} \times \mathrm{N}$ & 0.0078 & 0.0068 & 0.0004 & 0.0020 \\
\hline$Y \times I \times N$ & 0.2595 & 0.0018 & $<0.0001$ & 0.0008 \\
\hline
\end{tabular}

† GY is grain yield, ANU is aboveground nitrogen uptake, BSN is basal stalk nitrate nitrogen, NFRE is nitrogen fertilizer recovery efficiency. $\ddagger$ Year includes 2009 and 2010.

§ Irrigation treatments include fully-irrigated (FI) and water-stressed (WS).

TI Nitrogen management systems include split applied urea (split-U), pre-plant applied urea, polymer-coated urea (PCU) and urea with inhibitors (IU) each at $\mathrm{N}$ rates of $180 \mathrm{~kg} \mathrm{~N} \mathrm{ha}^{-1}$, and split- $U$ and PCU each at $\mathrm{N}$ rates of $225 \mathrm{~kg} \mathrm{~N} \mathrm{ha}^{-1}$.

Table 4. Means of crop response variables in the source/timing/rate study where the year $\times$ irrigation $\times \mathrm{N}$ management system interaction effect was significant.

\begin{tabular}{|c|c|c|c|c|}
\hline \multirow[b]{2}{*}{ N Management system $\dagger$} & \multicolumn{2}{|c|}{2009} & \multicolumn{2}{|c|}{2010} \\
\hline & $\mathrm{Fl} \ddagger$ & WS & $\mathrm{FI}$ & WS \\
\hline & \multicolumn{4}{|c|}{ ANU§, kg N ha } \\
\hline Split-U I80 & 223abף & I72efghi & $196 \mathrm{bcde}$ & I62fghij \\
\hline Split-U 225 & $230 a$ & 196bcde & $189 c d e f$ & I59ghij \\
\hline Pre-U I80 & I44ijk & 185defg & $118 \mathrm{kl}$ & $89 m$ \\
\hline PCU 180 & I6Ifghij & $200 \mathrm{bcde}$ & I56 hij & $\mid 23 \mathrm{kl}$ \\
\hline PCU 225 & $20 \mathrm{lbcde}$ & $216 a b c$ & I88cdef & I37jk \\
\hline \multirow[t]{2}{*}{ IU I80 } & 18Idefgh & 203abcd & I6 Ifghij & $108 \mathrm{~lm}$ \\
\hline & \multicolumn{4}{|c|}{ BSN\#, mg NO${ }_{3}-\mathrm{N} \mathrm{kg}^{-1}$} \\
\hline Split-U I80 & $22 \mathrm{hi}$ & $90 \mathrm{fgh}$ & $565 c d$ & $2003 a b$ \\
\hline Split-U 225 & 350def & 286de & $1062 a b c$ & $2513 a$ \\
\hline pre-U I80 & $17 i$ & I288abc & $58 \mathrm{efg}$ & I55fgh \\
\hline PCU 180 & $9 i$ & $570 \mathrm{abc}$ & 200def & 281 def \\
\hline PCU 225 & 46ghi & $1636 a b$ & $637 \mathrm{bcd}$ & $1973 a b$ \\
\hline \multirow[t]{2}{*}{ IU I80 } & $16 i$ & I299abc & 90 efg & $914 a b c$ \\
\hline & \multicolumn{4}{|c|}{ NFRE, $\%$} \\
\hline Split-U I80 & $83 a$ & $65 \mathrm{cde}$ & $67 \mathrm{bcde}$ & 69abcd \\
\hline Split-U 225 & 70abcd & $63 c d e f$ & 50fghij & 54efghi \\
\hline Pre-U I80 & $40 \mathrm{ijk}$ & $72 a b c$ & 231 & $29 \mathrm{kl}$ \\
\hline PCU 180 & 49fghij & $81 a b$ & 44hij & 47ghij \\
\hline PCU 225 & 57defgh & $7 \mathrm{labc}$ & 50fghij & 44hij \\
\hline IU 180 & $60 \mathrm{cdefg}$ & $82 a$ & 47ghij & $39 j k$ \\
\hline
\end{tabular}

† N management systems include split applied urea (split-U), preplant applied urea, polymer-coated urea (PCU) and urea with inhibitors (IU) each at $\mathrm{N}$ rates of $180 \mathrm{~kg} \mathrm{~N} \mathrm{ha}^{-1}$, and split-U and PCU each at $\mathrm{N}$ rates of $225 \mathrm{~kg} \mathrm{~N} \mathrm{ha}{ }^{-1}$.

¥ Irrigation treatments includes fully-irrigated (FI) and water-stressed (WS).

$\S$ ANU is aboveground nitrogen uptake, BSN is basal stalk nitrate nitrogen, NFRE is nitrogen fertilizer recovery efficiency.

TI Within a response variable, means followed by the same letter are not significantly different $(P<0.05)$.

\# Original analyses were conducted on the log of BSN data to meet homogeneity of variance requirements but the untransformed data are presented here.

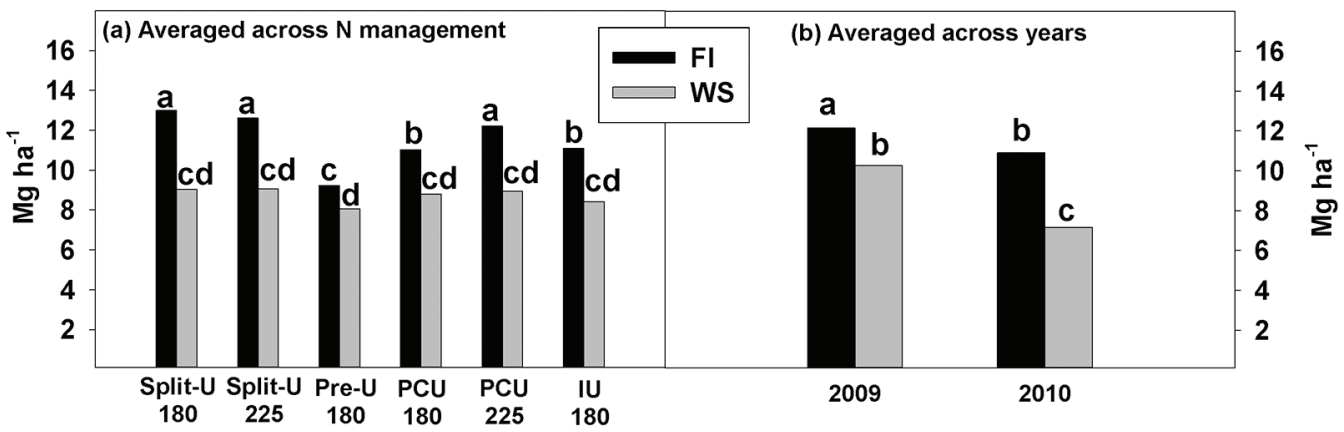

Fig. 6. Mean grain yield in the source/timing/rate study for fully-irrigated (FI) and water-stressed (WS) treatments in 2009 and 2010 under different $\mathrm{N}$ management systems, which included split applied urea (Split-U), pre-plant applied urea (Pre-U), polymer-coated urea (PCU), and urea with inhibitors (IU) each at $\mathrm{N}$ rates of $180 \mathrm{~kg} \mathrm{~N} \mathrm{ha}^{-1}$, and Split-U and PCU each at N rates of $225 \mathrm{~kg} \mathrm{~N} \mathrm{ha}^{-1}$ averaged across (a) years and (b) $\mathrm{N}$ management systems. Means with the same letter are not significantly different $(P<0.05)$. 
The interacting effects of irrigation $\times \mathrm{N}$ rate and year $\times \mathrm{N}$ rate on GY caused the response to vary in terms of slope and in estimates of EONR and AONR. However, while irrigation had a positive effect on GY, mean EONR and AONR values did not differ significantly by irrigation or year. The mean values of AONR exceeded the corresponding EONR mean values by 22 and $26 \mathrm{~kg} \mathrm{~N} \mathrm{ha}^{-1}$ in the FI and WS treatments, respectively. However, the increases in GY corresponding to AONRs compared to ENORs was small $\left(0.1 \mathrm{Mg} \mathrm{ha}^{-1}\right)$ and insignificant in both FI and WS. In 2010, where $\mathrm{N}$ was more prone to loss through leaching and GYs were less than in 2009, the mean AONR value averaged across irrigation regimes exceeded the mean EONR value by $25 \mathrm{~kg} \mathrm{~N}^{-1}$ with a corresponding increase in GY of $0.6 \mathrm{Mg} \mathrm{ha}^{-1}$. In 2009, GY increased by a smaller amount $\left(0.1 \mathrm{Mg} \mathrm{ha}^{-1}\right)$ for a $28 \mathrm{~kg} \mathrm{~N} \mathrm{ha}^{-1}$ increase in applied $\mathrm{N}$ corresponding to the difference between mean EONR and AONR values. The lack of a relationship between yield goal and optimum $\mathrm{N}$ rate when numerous studies are combined may in part be due to variability in soil water availability and unaccounted for $\mathrm{N}$ loss.

In 2010, the NFRE response curve was more linear than in 2009, where the curve was C-shaped with the greatest NFRE at $135 \mathrm{~kg} \mathrm{~N} \mathrm{ha}^{-1}$ (Fig. 4c). Aboveground $\mathrm{N}$ uptake increased with increasing $\mathrm{N}$ rate; however, since the NFRE calculation is based on the difference in $\mathrm{N}$ uptake between the fertilized and control plots, these low $\mathrm{N}$ yields skewed the NFRE calculation in favor of lower $\mathrm{N}$ rates. Such inverse relationship between crop N uptake and NFRE was also reported in a tillage study (Venterea et al., 2011). In the current study, NFRE tended to decrease with increasing $\mathrm{N}$ rates suggesting that the lower $\mathrm{N}$ rates used fertilizer $\mathrm{N}$ more efficiently compared to higher $\mathrm{N}$ rates.

The BSN test has been demonstrated to be an effective diagnostic tool to detect excessive $\mathrm{N}$ application in the previous crop (Binford et al., 1990, 1992). Current Iowa State University recommendations (Blackmer and Mallarino, 1996) for $\mathrm{N}$ management identify four BSN categories: low (<250 $\left.\mathrm{mg} \mathrm{kg}^{-1}\right)$, marginal (250-700 $\left.\mathrm{mg} \mathrm{kg}^{-1}\right)$, optimal $\left(700-2000 \mathrm{mg} \mathrm{kg}^{-1}\right)$ and excessive $\left(>2000 \mathrm{mg} \mathrm{kg}^{-1}\right)$. In this study, BSN values corresponding to AONRs in both years were within optimal categories when averaged over irrigation management. Although, in general, BSN values were lower in 2009 than 2010, yield potential was greater in 2009 than 2010 and therefore, a greater fraction of $\mathrm{N}$ taken up by crop could have been consumed in grain filling in 2009 than in 2010, thereby leaving less $\mathrm{N}$ accumulated in corn stalks in 2009. Basal stalk $\mathrm{NO}_{3}{ }^{-}-\mathrm{N}$ corresponding to AONRs also suggests a positive effect of irrigation on grain $\mathrm{N}$ uptake. The BSN values were in the low category at lower rates of applied urea-N and increased with increased application of $\mathrm{N}\left(r^{2}=0.44, P<0.0001\right)$ as was observed by Binford et al. (1990). The increase in BSN was steeper at greater $\mathrm{N}$ rates in WS plots than in the FI (Fig. 3b). Other than excessive use of $\mathrm{N}$ input, any extreme event that can cause plant stress can also lead to increased values of BSN. In this study, the WS treatments had increased BSN primarily caused by reduced water input, which eventually affected GY. In such conditions of limited yield potential, addition of more fertilizer may result in accumulation of BSN indicating that greater rates of fertilization would not have increased GY. These results suggest that BSN is an effective end-of-season diagnostic tool to determine excessive $\mathrm{N}$ input, but in some cases may potentially be confounded with severe weather conditions such as drought stress.

\section{Source/Timing/Rate Study}

Basal stalk $\mathrm{NO}_{3}{ }^{-}-\mathrm{N}$ concentration was greater in WS than in FI in most of treatments in both years but GY was in reverse order (FI > WS). In 2010, BSN was in the excessive range in the WS treatments with split-U. These results indicate that the reduced GY in the WS treatment was a result of a lack of timely and amount of water input through irrigation and resulted in $\mathrm{NO}_{3}{ }^{-}-\mathrm{N}$ accumulation in basal stalks. Therefore, while interpreting BSN accumulation, appropriate consideration is warranted for factors such as water management, insect damage, weed infestation, or weather conditions which can limit crop grow th early in the season and as a result, $\mathrm{N}$ input ends up accumulating as BSN in lieu of increasing yields.

Irrigation did not affect NFRE for any of $\mathrm{N}$ treatments in 2010 and had a mixed effect on NFRE in 2009. In FI treatments, NFRE was greater with split $U$ than pre-U, PCU, or IU at the $180 \mathrm{~kg} \mathrm{~N} \mathrm{ha}^{-1}$ rate and there was no difference between split-U and PCU both applied at $225 \mathrm{~kg} \mathrm{~N} \mathrm{ha}^{-1}$. In WS treatments, NFRE was less consistent with $\mathrm{N}$ treatments.

Grain yield was not affected by $\mathrm{N}$ source/timing/rate in the WS treatment, in contrast to the FI treatment. In WS plots, sustaining prolonged availability of $\mathrm{N}$ in soil for plant uptake through the use of PCU or IU, or split application of urea did not increase GY compared to pre-U (Fig. 5). This signifies that there was no economic return on the extra costs of these practices.

In FI plots, the split- $U$ treatment at the lower $\mathrm{N}$ rate (180 kg N ha ${ }^{-1}$ ) had greater GY than other $\mathrm{N}$ sources applied at same rate and it also had similar GY as other $\mathrm{N}$ sources applied at higher $\mathrm{N}$ rate $\left(225 \mathrm{~kg} \mathrm{~N} \mathrm{ha}^{-1}\right.$ ) (Fig. 6). Urea when applied pre-plant resulted in the lowest of all yields, thus indicating pre-plant urea application is not an efficient $\mathrm{N}$ management practice in irrigated sandy soil corn production. The risk of $\mathrm{N}$ loss through leaching increases when $\mathrm{N}$ fertilizer is applied in a onetime application at planting or preplant. Therefore, splitting $\mathrm{N}$ application is considered a best management practice (Lamb et al., 2015; Gehl et al., 2005; Abdin et al., 1996). In addition to less potential for $\mathrm{N}$ leaching to ground water, split application of $\mathrm{N}$ fertilizer is also very important to achieve high corn yields on irrigated sandy soils (Lamb et al., 2015). When $\mathrm{N}$ management was improved with split $\mathrm{N}$ application as practiced in the current study, Gehl et al. (2005) reported that maximum corn yield on irrigated sandy soils could be achieved at much lower $(>50 \%) \mathrm{N}$ rate compared to $\mathrm{N}$ recommendation for one-time application.

Numerous studies have indicated that alternate $\mathrm{N}$ sources such as PCU and IU make $\mathrm{N}$ more available for plant uptake before it is lost because of the slow $\mathrm{N}$ release through coating (in case of PCU) and slow transformation of urea- $\mathrm{N}$ into $\mathrm{NH}_{4}{ }^{+}$and subsequently to $\mathrm{NO}_{3}{ }^{-}$through chemical inhibitions (in case of IU) (Gagnon et al., 2012; Noellsch et al., 2009). In the current study with adequate irrigation, both alternate $\mathrm{N}$ sources (PCU and IU), applied at pre-plant performed better than pre-plant urea but did not perform as well as split-U. Urea when split applied reduces $\mathrm{N}$ loss compared to one-time pre-plant applied urea and keeps $\mathrm{N}$ readily available 
for crops throughout season. Based on the results of this study, split- $U$ application was the most efficient $\mathrm{N}$ treatment in terms of yield per unit applied N. Further studies are needed to evaluate timing of PCU and IU relative to split-U. Delaying application of PCU or IU to shortly after emergence may be more effective than a pre-plant broadcast application.

\section{CONCLUSIONS}

Irrigation did not affect EONR or AONR but increased GY and ANU at corresponding $\mathrm{N}$ rates. Thus, under the conditions of this study, the $\mathrm{N}$ rate at which maximum grain yield was achieved (ANOR), and the recommended $\mathrm{N}$ rate based on economic factors (EONR), were not related to grain yield level. As $\mathrm{N}$ rate increased, NFRE decreased indicating that fertilizer $\mathrm{N}$ uptake and GY per unit $\mathrm{N}$ uptake were less efficient at higher $\mathrm{N}$ rates. When irrigated, split applications of urea produced superior corn GY and NFRE when compared to pre-plant applications of specialized $\mathrm{N}$ sources (PCU, IU) all applied at same rate. With proper irrigation, a one-time pre-plant applied PCU and IU performed better than similarly applied urea and provides an alternative if for some reason, one cannot opt for split applications. The finding that GY did not respond to $\mathrm{N}$ source and timing under water stress, in contrast with the significant responses observed under full-irrigation, may have important implications in areas within the United States and across the world where changes in irrigation practices are expected under future climate conditions. Further study is needed to evaluate these effects across a range of soil, climate, and management conditions.

\section{ACKNOWLEDGMENTS}

The authors gratefully acknowledge the assistance of M. Dolan, R. Faber, C.R. Hyatt, M. McNearney, A. Scobbie, and T. Sellie. This work was supported in part by a grant from the Minnesota Corn Research and Promotion Council.

\section{REFERENCES}

Abdin, M.Z., K.C. Bansal, and Y.P. Abrol. 1996. Effect of split nitrogen application on growth and yield of wheat (T. aestivum L.) genotypes with different $\mathrm{N}$-assimilation potential. J. Agron. Crop Sci. 176:83-90. doi:10.1111/j.1439-037X.1996.tb00450.x

Al-Kaisi, M.M., and X. Yin. 2003. Effects of nitrogen rate, irrigation rate, and plant population on corn yield and water use efficiency. Agron. J. 95:1475-1482. doi:10.2134/agronj2003.1475

Barr, L., S.C. Mason, M.J. Novacek, C.S. Wortmann, and J.M. Rees. 2013. Row spacing and seeding rates recommendations for corn in Nebraska. G2216. Univ. of Nebraska-Lincoln Ext., Lincoln. http://extensionpublications.unl.edu/assets/pdf/g2216.pdf (accessed 13 Apr. 2016).

Binford, G.D., A.M. Blackmer, and N.M. El-Hout. 1990. Tissue test for excess nitrogen during corn production. Agron. J. 82:124129. doi:10.2134/agronj1990.00021962008200010027x

Binford, G.D., A.M. Blackmer, and B.G. Meese. 1992. Optimal concentrations of nitrate in cornstalks at maturity. Agron. J. 84:881887. doi:10.2134/agronj1992.00021962008400050022x

Blackmer, A.M. and A.P. Mallarino. 1996. Cornstalk testing to evaluate nitrogen management. Agronomy 8-5. PM 1584 (Revised). Iowa State Univ. Ext. http://store.extension.iastate.edu/Product/Cornstalk-Testing-to-Evaluate-Nitrogen-Management (accessed 3 June 2016).
Blackmer, A.M., R.D. Voss, and A.P. Mallarino. 1997. Nitrogen fertilizer recommendations for corn in Iowa. PM 1714. Iowa State Univ. Ext., Ames.

Carlson, R.M., R.I. Cabrera, J.L. Paul, J. Quick, and R.Y. Evans. 1990. Rapid direct determination of ammonium and nitrate in soil and plant tissue extracts. J. Plant Nutr. 21:1519-1529.

Cerrato, M.E., and A.M. Blackmer. 1990. Comparison of models for describing corn yield response to nitrogen fertilizer. Agron. J. 82:138-143. doi:10.2134/agronj1990.00021962008200010030x

Combs, S.M., and M.V. Nathan. 1998. Recommended soil organic matter tests. In: J.R. Brown, editor, Recommended chemical soil test procedures for the North Central Region. NCR Publ. no. 221 (revised). SB 1001. Missouri Agric. Exp. Stn. http://extension.missouri.edu/explorepdf/specialb/sb1001.pdf (accessed 3 June 2016).

El-Hendawy, S.E., and U. Schmidhalter. 2010. Optimal coupling combinations between irrigation frequency and rate for drip-irrigated maize grown on sandy soil. Agr. Water Manage. 97:439-448. doi:10.1016/j.agwat.2009.11.002

Endelman, F.J., D.R. Keene, J.T. Gilmour, and P.G. Saffigna. 1974. Nitrate and chloride movement in the Plainfield loamy sand under intensive irrigation. J. Environ. Qual. 3:295-298. doi:10.2134/jeq1974.00472425000300030024x

Frank, K., D. Beegle, and J. Denning. 1998. Recommended phosphorus tests. In: J.R. Brown, editor, Recommended chemical soil test procedures for the North Central Region. NCR Publ. no. 221 (revised). SB 1001. Missouri Agric. Exp. Stn. http://extension.missouri.edu/explorepdf/specialb/sb1001.pdf (accessed 3 June 2016).

Fujinuma, R., N.J. Balster, and J.M. Norman. 2009. An improved model of nitrogen release for surface-applied controlled-release fertilizer. Soil Sci. Soc. Am. J. 73:2043-2050. doi:10.2136/ sssaj2009.0085

Gagnon, B., N. Ziadi, and C. Grant. 2012. Urea fertilizer forms affect grain corn yield and nitrogen use efficiency. Can. J. Soil Sci. 92:341-351. doi:10.4141/cjss2011-074

Gehl, R.J., J.P. Schmidt, L.D. Maddux, and W.B. Gordon. 2005. Corn yield response to nitrogen rate and timing in sandy irrigated soils. Agron. J. 97:1230-1238. doi:10.2134/agronj2004.0303

Gelderman, R.H., and D. Beegle. 1998. Recommended nitrate-nitrogen tests. In: J.R. Brown, editor, Recommended chemical soil test procedures for the North Central Region. NCR Publ. no. 221 (revised). SB 1001. Missouri Agric. Exp. Stn. http://extension.missouri.edu/explorepdf/specialb/sb1001.pdf (accessed 3 June 2016).

Halvorson, A.D., S.J. Del Grosso, and F. Alluvione. 2010. Tillage and inorganic nitrogen source effects on nitrous oxide emissions from irrigated cropping systems. Soil Sci. Soc. Am. J. 74(2):436-445. doi:10.2136/sssaj2009.0072

Hanway, J.J., and A.L. Englehorn. 1958. Nitrate accumulation in some Iowa crop plants. Agron. J. 50:331-334. doi:10.2134/agronj1958 $.00021962005000060013 \mathrm{x}$

Hyatt, C.R., R.T. Venterea, and C.J. Rosen. 2010. Polymer-coated urea maintains urea potato yields and reduces nitrous oxide emissions in a Minnesota loamy sand. Soil Sci. Soc. Am. J. 74(2):419-428. doi:10.2136/sssaj2009.0126

Karam, F., J. Breidy, C. Stephan, and J. Rouphael. 2003. Evapotranspiration, yield and water use efficiency of drip irrigated corn in the Bekaa Valley of Lebanon. Agric. Water Manage. 63(2):125-137. doi:10.1016/S0378-3774(03)00179-3

Lamb, J. A., Rosen, C. J., Bongard, P. M., Kaiser, D. E., Fernandez, F. G., and B. L. Barber. 2015. Fertilizing corn grown on irrigated sandy soils. AG-NM-1501. Univ. of Minnesota Ext. Serv., St. Paul.

Littell, R.C., G.A. Milliken, W.W. Stroup, R.D. Wolfinger, and O. Schabenberger. 2006. SAS for mixed models. 2nd ed. SAS Inst., Cary. NC. 
Liu, J., C. Folberth, H. Yang, J. Rockstrom, K. Abbaspour, and A.J.B. Zehnder. 2013. A global and spatially explicit assessment of climate change impacts on crop production and consumptive water use. PLoS One 8(2):e57750 doi:10.1371/journal.pone.0057750.

Ludwick, A.E., J.E. Reuss, and E.J. Langin. 1976. Soil nitrates following four years continuous corn and as surveyed in irrigated farm fields of central and eastern Colorado. J. Environ. Qual. 5:82-86. doi:10.2134/jeq1976.00472425000500010019x

Maharjan, B., R.T. Venterea, and C. Rosen. 2014. Fertilizer and irrigation management effects on nitrous oxide emissions and nitrate leaching. Agron. J. 106:703-714. doi:10.2134/agronj2013.0179

McDonald, R.I. and E.H. Girvetz. 2013. Two challenges for U.S. irrigation due to climate change: Increasing irrigated area in wet states and increasing irrigation rates in dry states. PLoS ONE 8(6):e65589. doi:10.1371/journal.pone.0065589

MCWG. 2013. Past climate data for Minnesota. Minnesota Climatology Working Group. http://climate.umn.edu/ (accessed July 2014).

Mulvaney, R.L., A.A. Khan, R.G. Hoeft, and H.M. Brown. 2001. A soil organic nitrogen fraction that reduces the need for nitrogen fertilization. Soil Sci. Soc. Am. J. 65:1164-1172. doi:10.2136/ sssaj2001.6541164x

NeSmith, D.S., and J. T. Ritchie. 1992. Short- and long-term responses of maize to a preanthesis soil water deficit. Agron. J. 84:107-113. doi:10.2134/agronj1992.00021962008400010021x

Noellsch, A.J., P.P. Motavalli, K.A. Nelson, and N.R. Kitchen. 2009. Corn response to conventional and slow-release nitrogen fertilizers across a claypan landscape. Agron. J. 101:607-614. doi:10.2134/agronj2008.0067x

Oktem, A. 2008. Effect of water shortage on yield and protein and mineral compositions of drip-irrigated sweet corn in sustainable agricultural systems. Agric. Water Manage. 95:1003-1010. doi:10.1016/j.agwat.2008.03.006

Pandey, R.K., J.W. Maranville, and A. Admou. 2000. Deficit irrigation and nitrogen effects on maize in a Sahelion environment I. Grain yield and yield component. Agric. Water Manage. 46:1-13. doi:10.1016/S0378-3774(00)00073-1

Peters, J., M. Nathan, and C. Laboski. 2012. pH and lime requirement. In: J.R. Brown, editor, Recommended chemical soil test procedures for the North Central Region. NCR Publ. no. 221 (revised). SB 1001. Missouri Agric. Exp. Stn. http://extension.missouri.edu/ explorepdf/specialb/sb1001.pdf (accessed 3 June 2016).

Rehm, G., J. Lamb, C. Rosen, and G. Randall. 2008. Best management practices for nitrogen on coarse textured soils. Univ. of Minnesota Ext. Service, St. Paul.

SAS Institute. 2003. SAS System for Windows, Release 9.1. SAS Inst., Cary, NC.

Sawyer, J., E. Nafziger, G. Randall, L. Bundy, G. Rehm, and B. Joern. 2006. Concepts and rationale for regional nitrogen rate guidelines for corn. Iowa State Univ. Ext. and Outreach. www.extension.iastate.edu/publications/pm2015.pdf (accessed July 2014).
Simsek, M., A. Can, N. Denek, and T. Tonkaz. 2011. The effects of different irrigation regimes on yield and silage quality of corn under semi-arid conditions. Afr. J. Biotechnol. 10(31):5869-5877.

Sistani, K.R., M. Jn-Baptiste, N. Lovanh, and K.L. Cook. 2011. Atmospheric emissions of nitrous oxide, methane, and carbon dioxide from different nitrogen fertilizers. J. Environ. Qual. 40:1797-1805. doi:10.2134/jeq2011.0197

Stanford, G. 1973. Rationale for optimum nitrogen fertilization in corn production. J. Environ. Qual. 2(2):159-166. doi:10.2134/ jeq1973.00472425000200020001x

Stone, K.C., C.R. Camp, E.J. Sadler, D.E. Evans, and J.A. Millen. 2010. Corn yield response to nitrogen fertilizer and irrigation in the southeastern coastal plain. Appl. Eng. Agric. 26(3):429-438. doi: $10.13031 / 2013.29954$

Stone, P.J., D.R. Wilson, J.B. Reid, and R.N. Gillespie. 2001. Water deficit effects on sweet corn. I. Water use, radiation use efficiency, growth, and yield. Aust. J. Agric. Res. 52:103-113. doi:10.1071/ AR99146

Venterea, R.T., C.R. Hyatt, and C.J. Rosen. 2011. J. Fertilizer management effects on nitrate leaching and indirect nitrous oxide emissions in irrigated potato production. J. Environ. Qual. 40:1103-1112. doi:10.2134/jeq2010.0540

Warncke, D., and J.R. Brown. 1998. Potassium and other basic cations. In: J.R. Brown, editor, Recommended chemical soil test procedures for the North Central Region. NCR Publ. no. 221 (revised). SB 1001. Missouri Agric. Exp. Stn. http://extension.missouri.edu/ explorepdf/specialb/sb1001.pdf (accessed 3 June 2016).

Wilson, M. L., C. J. Rosen, and J. F. Moncrief. 2010. Effects of polymer-coated urea on nitrate leaching and nitrogen uptake by potato. J. Environ. Qual. 39:492-499.

Wright, J. 2002. Irrigation scheduling: Checkbook method. FO-01322. Univ. of Minnesota Ext. Serv., St. Paul.

Yi, L., S. Yufang, Y. Shenjiao, L. Shiqing, and C. Fang. 2011. Effect of mulch and irrigation practices on soil water, soil temperature and the grain yield of maize (Zea mays L) in Loess Plateau, China. Afr. J. Agric. Res. 6(10):2175-2182.

Yoshikawa, S., J. Cho, H.G. Yamada, N. Hanasaki, and S. Kanae. 2014. An assessment of global net irrigation water requirements from various water supply sources to sustain irrigation: Rivers and reservoirs (1960-2050). Hydrol. Earth Syst. Sci. 18:42894310. doi:10.5194/hess-18-4289-2014

Zebarth, B. J., J. W. Paul, M. Younie, and S. Bittman. 2001. Fertilizer nitrogen recommendations for silage corn in high-fertility environment based on pre-sidedress soil nitrate test. Commun. Soil Sci. Plan. 32:17-18, 2721-2739. doi:10.1081/CSS-120000957

Zvomuya, F., C.J. Rosen, M.P. Russelle, and S.C. Gupta. 2003. Nitrate leaching and nitrogen recovery following application of polyolefin-coated urea to potato. J. Environ. Qual. 32:480-489. doi: $10.2134 /$ jeq2003.4800 